\title{
Fundamento central do direito à não autoincriminação
}

\author{
Central foundation of the right against self-incrimination
}

Heloisa Rodrigues Lino de Carvalho ${ }^{1}$

Universidad de Morón - Argentina heloisalinocarvalho@gmail.com

http://lattes.cnpq.br/8240862426355988

https://orcid.org/0000-0001-5983-8156

\begin{abstract}
Resumo: A não autoincriminação, imanente sobretudo à área do Direito Processual Penal Constitucional, é um direito individual humano e fundamental, de observância obrigatória na persecução penal, previsto em importantes documentos internacionais de direitos humanos, bem como na maioria das Constituições democráticas. Utilizando-se uma metodologia científica por meio de pesquisa bibliográfica e método teórico dedutivo, objetiva-se analisar seu fundamento central. O princípio motriz da razão de sua existência é a dignidade humana, cujo aspecto particular mais sólido apontado é a integridade mental e moral. Esta é violada ao ser o indivíduo colocado frente a possíveis disjuntivas desagradáveis, constituídas da possibilidade de dar origem a consequências negativas, seja por optar manter-se em silêncio ou declarar e, neste caso, por se autoincriminar (admitindo a imputação, sendo verdadeira ou não) ou por mentir. Isso transgride a natureza humana, que tem dificuldade de admitir as próprias falhas e assumir as consequências daí advindas. A vedação de se obrigar o acusado a emitir uma declaração e de se atribuir qualquer consequência negativa ao seu silêncio é uma decorrência incontestável desse direito. No entanto, sua aplicabilidade nos diferentes casos concretos enseja muitas controvér-
\end{abstract}

1 Doutoranda em Ciências Jurídicas pela Universidad de Morón (Arg). Bacharela em Direito pelo Instituto Vianna Junior (2001) e pós-graduada Especialista em Direito Público com ênfase em Direito Processual Civil pela Universidade Potiguar (RN/ $\mathrm{Br})$ (2007). Atualmente é oficiala de justiça avaliadora federal na Justiça Federal Seção Judiciária do Espírito Santo e Professora de Introdução ao Estudo do Direito nos Cursos de Formação de Soldados da Polícia Militar do Espírito Santo. 
sias. A delimitação de seu real fundamento objetiva contribuir com subsídios para coerentes soluções.

Palavras-chave: Autoincriminação; Nemo tenetur se detegere; Silêncio; Direito de não declarar contra si mesmo; Direito de não se confessar culpado.

ABSTRACT: Non-self-incrimination, immanent especially in Constitutional Criminal Procedural Law, is an individual and fundamental human right. Its observance is mandatory in criminal prosecution, provided for in important international human rights documents, as well as in most of the democratic Constitutions. Employing a scientific methodology by means of bibliographical research and theoretical deductive method, the objective is to analyze its central foundation, to be able to outline its scope more accurately. The main driver for its existence is human dignity, whose most solid aspect is a person's mental and moral integrity. This is violated when the individual faces possible unpleasant disjunctives, marked by the possibility of giving rise to negative consequences. The person ends up either opting to remain silent or testify and, in this case, they may self-incriminate (admitting imputation, whether true or not) or by lie. This transgresses human nature, since we have difficulty admitting our own faults and bearing with the consequences thereof. The prohibition of compelling the accused to issue a statement and attributing any negative consequences to their silence is an undeniable consequence of that right. However, its applicability in different concrete cases incites many controversies. The outline of its real foundation aims at contributing with subsidies for coherent solutions.

KEYWORDS: Self-incrimination; Nemo tenetur se detegere; Silence; Right not to testify against yourself; Right not to plea guilty.

SUMÁRIO: Introdução; 1. O tratamento do direito à não autoincriminação em alguns ordenamentos jurídicos; 2. Fundamentos do direito à não autoincriminação; 3. Análise dos argumentos apresentados; Conclusão; Referências.

\section{INTRODUÇÃO}

Este trabalho situa-se na área do Direito Processual Penal Constitucional. Tem-se o objetivo de analisar o fundamento central do direito 
à não autoincriminação. Para isso se utiliza uma metodologia científica por meio de pesquisa bibliográfica e do método teórico dedutivo. Estruturalmente, divide-se em introdução, desenvolvimento, conclusão e referências. O desenvolvimento está dividido em três partes, onde expõem-se no item 1 o tratamento do direito à não autoincriminação em alguns ordenamentos jurídicos, no item 2 os fundamentos do direito à não autoincriminação encontrados na bibliografia jurídica, e no item 3 a análise dos argumentos apresentados.

Justifica-se na relevância do direito à não autoincriminação, que é um direito individual, humano e fundamental, de observância obrigatória na persecução penal, previsto em importantes documentos internacionais de direitos humanos, como no Pacto Internacional de Direitos Civis e Políticos (PIDCP) e na Convenção Americana de Direitos Humanos (CADH), bem como na maioria das Constituições democráticas. Assim, é imprescindível determinar a razão de sua existência, a fim de que se possa delimitar com maior precisão sua abrangência.

O direito à não autoincriminação tem grande influência na licitude das provas. Não existe um consenso se essa garantia, além do direito de permanecer em silêncio, de não se confessar e de não sofrer consequências negativas ao exercício do silêncio, abarca também o direito de mentir e, principalmente, o direito de não colaborar com a produção probatória na forma ativa e/ou passiva, como coleta de sangue, de amostra de parte do corpo para exame de DNA, fornecimento de material para perícia grafotécnica, submissão ao etilômetro, participação em reconstituição do crime etc. Entretanto, apesar de instigante, não se aprofundará nessas questões, a fim de não extrapolar o objetivo aqui proposto, que é uma análise em abstrato desse direito, com o propósito de delimitar seu fundamento central. Ressalta-se que essa delimitação contribui com subsídios para coerentes soluções dos casos concretos.

O problema gira em torno de determinar qual é o fundamento central do direito à não autoincriminação. Para essa análise, fazem-se alguns questionamentos. Como esse direito é tratado nos diversos ordenamentos jurídicos, especialmente na América Latina? Quais os principais fundamentos apontados pelos juristas? Qual a consistência dos fundamentos apontados? Qual o fundamento que mais bem justifica a existência desse direito? Qual é sua principal decorrência? 
A compreensão do direito à não autoincriminação varia nos diversos ordenamentos jurídicos, em especial nos Estados Unidos e Europa em relação aos países latino-americanos. Assim, apresenta-se seu tratamento jurídico em alguns países, especialmente, na América Latina, apenas de forma genérica, somente com o intuito de contextualizar a sua aplicação, já que o foco é a análise do seu fundamento central.

Os fundamentos apontados na literatura jurídica são vários, como a dificuldade humana em confessar seus próprios erros, a coibição de tortura para se obter uma confissão, a presunção de inocência, a tutela de direitos inerentes à dignidade humana, dentre eles a integridade física, mental e moral, a liberdade de autodeterminação e de consciência e a autopreservação. Há também o argumento de que a razão de existência desse direito é a elisão da imoralidade de se pôr alguém frente a possíveis disjuntivas desagradáveis, denominadas de "trilema", consistente na possibilidade de dar origem a consequências negativas, seja por optar por manter-se em silêncio ou por declarar, e, neste caso, por se autoincriminar (admitindo os fatos imputados, sejam eles verdadeiros ou não) ou por mentir.

Como hipótese a se comprovar, estabelece-se que o princípio motriz da razão de existência do direito à não autoincriminação é a dignidade humana, cujo aspecto particular que se visa proteger é a integridade mental, moral e até física, violada pelo denominado "trilema”. Essa violação transgride a natureza humana, que tem dificuldade de admitir as próprias falhas e assumir as consequências daí advindas. A principal decorrência desse direito é a vedação de se obrigar o acusado a emitir uma declaração e de se atribuir qualquer consequência negativa ao seu silêncio.

Apesar de existirem correntes filosóficas que negam a existência de uma natureza humana, adota-se aqui a teoria de que os seres humanos, assim como qualquer outro ser do universo, possuem uma natureza própria. É complexo, no entanto, determinar precisamente o que vem a ser a natureza humana, o que só será alcançado com estudos interdisciplinares em vários campos da ciência que analisam a espécie humana e procuram entender sua natureza, dentre eles a genética do comportamento, a antropologia, a biologia evolutiva, a primatologia, a psicologia e a neurociência. ${ }^{2}$

2 FERNANDEZ, Atahualpa. O problema da natureza humana (parte 1 e 2). Empório do Direito, Florianópolis/SC, jul. 2015. 
Considera-se natureza humana a essência, a índole, do ser humano, constituindo-se em sua maneira peculiar de ser, de se comportar, sendo invariável, permanente e identificador do homem ${ }^{3}$. Um traço característico do ser humano é possuir uma natureza essencial e intensamente social, ou seja, necessita viver em comunidade, e é dotado geneticamente de competência linguística e preparado para aprender e transmitir o conhecimento ${ }^{4}$.

Expõem-se os fundamentos apontados sobre o direito à não autoincriminação, as maneiras que possibilitam sua efetivação, bem como as consequências dele decorrentes, analisando os argumentos apresentados e verificando sua consistência. Enfim, apresentam-se as conclusões alcançadas.

\section{O tRatamento do direito À não AUtOINCRIMINAÇão EM ALGUNS ORDENAMENTOS JURÍDICOS}

O direito à não autoincriminação é também conhecido pelas expressões latinas, dentre outras, nemo tenetur se detegere e nemo tenetur se ipsum accusare, significando que ninguém é obrigado a se descobrir, se revelar, se autoincriminar ${ }^{5}$. Foi ignorado pelas civilizações clássicas e durante a Idade Média. Seu gradativo fortalecimento começou com o Iluminismo ${ }^{6}$. Porém, existem referências antigas, como aponta Luigi Ferrajoli ${ }^{7}$, citando Hobbes em sua obra "O Leviatã": "Se um homem é interrogado pelo soberano ou por um oficial seu relativamente a um delito por ele cometido, ele não é obrigado a confessar sem asseguração de perdão, pois ninguém pode ser obrigado por um pacto a acusar-se a si mesmo".

3 BEUCHOT, Mauricio; JAVIER, Saldaña. Derechos humanos y naturaleza humana. Ciudad de México: Universidad Nacional Autónoma de México, 2000, p. 61.

4 FERNANDEZ, Atahualpa. O problema da natureza humana (parte 1 e 2). Empório do Direito, Florianópolis/SC, jul. 2015.

5 QUEIJO, Maria Elizabeth. O direito de não produzir prova contra si mesmo: o princípio nemo tenetur se detegere e suas decorrências no processo penal. 2. ed. São Paulo: Saraiva, 2012, p. 28.

6 Ibidem, p. 30-34.

7 FERRAJOLI, Luigi. Direito e razão: teoria do garantismo penal. Tradução de Ana Paula Zomer Sica et al., 3. ed., São Paulo: Revista dos Tribunais, 2010, p. 625. 
Tal direito é consentâneo com o princípio norteador de todos os direitos humanos: dignidade da pessoa humana. Atualmente, encontra-se estabelecido tanto em normas de Direito Internacional Público quanto na maioria das Constituições dos Estados democráticos de direito, que geralmente repetem o texto daqueles documentos supranacionais.

Em âmbito internacional, é previsto explicitamente no PIDCP de $1966^{8}$ (art. 14, item 3, letra 'g'), na CADH de $1969^{\circ}$ (art. $8^{\circ}$, item 2, letra 'g', e item 3), no Protocolo Adicional I de 1977 às Convenções de Genebra de $1949^{10}$ (art. 75, item 4, letra 'f') e no Estatuto de Roma de $1998^{11}$ que instituiu o Tribunal Penal Internacional ou Corte Penal Internacional (art. 55).

O direito ao silêncio, pelo qual ninguém é obrigado a depor, a declarar, a manifestar-se oralmente contra si mesmo é, incontroversamente, a principal decorrência do direito à não autoincriminação. No entanto, de acordo com uma ampla posição doutrinária ${ }^{12}$, essa garantia abrange também o direito a não colaborar, ao menos de forma ativa, na produção de provas contra si mesmo.

O tratamento desse direito varia nos diversos ordenamentos jurídicos, em especial nos Estados Unidos e Europa em relação aos países

8 Disponível em: <http://direitoshumanos.gddc.pt/3_1/IIIPAG3_1_6.htm>. Acesso em: 02 mai. 2018.

9 Disponível em: <https://www.cidh.oas.org/basicos/portugues/c.convencao_americana.htm>. Acesso em: 27 abr. 2018.

10 Disponível em: <http://www.direitoshumanos.usp.br/index.php/Conven\%C3\%A7\%C3\%A3o-de-Genebra/protocolo-i-adicional-as-convencoes-de-genebra-de-12-de-agosto-de-1949-relativo-a-protecao-das-vitimas-dos-conflitos-armados-internacionais.html>. Acesso em: 27 abr. 2018.

11 Disponível em: <http://www.dhnet.org.br/direitos/sip/tpi/esttpi.htm>. Acesso em: 27 abr. 2018.

12 Paulo Mário Canabarro Trois Neto informa que diversos autores sustentam que, apesar da origem histórica, atualmente o direito à não autoincriminação abrangeria muito além do mero aspecto verbal da liberdade de declarar, alcançando uma ampla liberdade na colaboração da produção probatória, mesmo que não afete a integridade física ou mental do acusado. Sobre isso, ver: TROIS NETO, Paulo Mário Canabarro. O direito fundamental à não-autoincriminação e a influência do silêncio do acusado no convencimento do juiz penal. Dissertação (Mestrado) - Programa de Pós-Graduação em Direito, Universidade Federal do Rio Grande do Sul, Porto Alegre, 2009, p. 94. 
latino-americanos. Contudo, é unânime o reconhecimento do direito de permanecer calado diante de interrogatórios como decorrência do direito à não autoincriminação.

O Tribunal Europeu de Direitos Humanos (TEDH), em 2001, no caso J.B. contra Suíça, reafirmou que o direito de guardar silêncio e de não contribuir com a própria incriminação são normas internacionais geralmente reconhecidas. Apesar de não estarem expressas na Convenção Europeia de Direitos Humanos (CEDH), fazem parte do núcleo do art. $6^{\circ}$, pois se coadunam a evitar erros judiciários e a garantir a consecução de um processo justo. $\mathrm{O}$ direito à não autoincriminação impõe às autoridades o respeito à vontade do indivíduo, não podendo recorrer a provas obtidas por meio de coações ou pressões. ${ }^{13}$

No entanto, o TEDH entende que o direito de permanecer em silêncio, como parte do direito a um processo equitativo, não é absoluto e só existe na modalidade de não responder, não declarar. No caso John Murray contra Reino Unido, em 1996, compreendeu que a valoração negativa do silêncio do réu não viola o artigo $6^{\circ}$, itens 1 e 2 , da CEDH. Reputou, ainda, que poderia haver advertência de que o silêncio poderia ser usado para extrair inferências, as quais não seriam as únicas a embasarem a culpabilidade, bem como, por se tratar de terrorismo, essas inferências não eram contrárias à Convenção. Entretanto, considerou que o fato de o réu não ter tido advogado a tempo violou o conceito de equidade do julgamento. ${ }^{14}$

Nos Estados Unidos, tem-se o denominado "privilege against self-incrimination" advindo da Quinta Emenda à Constituição daquele país ${ }^{15}$. Esse direito permite que um indivíduo permaneça em silêncio

13 ECHAGÜE, Juan Manuel Álvarez. Reflexiones sobre el alcance del estado de inocencia y del principio de no autoincriminación en el derecho penal tributario. Revista de Tributación de la Asociación Argentina de Estudios Fiscales, Buenos Aires, n. 6, 2007, p. 7.

${ }^{14}$ CHARNIAK, Krystina. LegaVox.fr: The right to remain silent in UK and in USA, 1 set. 2012, [s/p].

15 [...] nor shall be compelled in any criminal case to be a witness against himself [...] (Disponível em: <https://www.usconstitution.net/xconst_Am5. html>. Acesso em: 27 abr. 2018). 
diante de um interrogatório tanto judicial quanto policial, não sendo obrigado a testemunhar contra si próprio ${ }^{16}$.

Lá o acusado não é obrigado a se manifestar, embora, se optar por declarar, fica obrigado a dizer a verdade, tendo que prestar juramento, estando sujeito à pena de perjúrio, caso minta ${ }^{17}$. No entanto, o silêncio do réu em sede policial pode, em certas circunstâncias, ser considerado indício ou prova do fato criminoso. ${ }^{18} \mathrm{~A}$ análise gira em torno de ter o interrogatório policial ocorrido antes da custódia ou sob ela e se o arguido foi informado de seus direitos ou se ele expressamente os invocou.

No caso Miranda v. Arizona (1966), a Suprema Corte norte-americana considerou que o interrogatório sob custódia contém em si coações que potencialmente afetam a liberdade do arguido de exercer o privilégio. Assim, decidiu que toda pessoa que estiver sob custódia deverá, antes de se submeter a interrogatório, ser advertida, dentre outras coisas, de seu direito de permanecer em silêncio, de que tudo que disser poderá ser usado contra ela e de que tem direito a um advogado. São as chamadas "advertências de Miranda”. Estando o arguido sob custódia, ele não é obrigado a invocar expressamente o seu direito ao silêncio. ${ }^{19}$

A custódia consiste numa prisão formal ou numa restrição da liberdade de locomoção em grau semelhante ao da prisão formal. No caso Miranda, a Corte não proibiu os interrogatórios sob custódia, mas obrigou os interrogadores a informar os suspeitos de seus direitos.

16 HAPNER, Andrew M. You have the right to remain silent, but anything you don't say may be used against you: the admissibility of silence as evidence after Salinas $v$. Texas. Florida Law Review, Gainesville (Florida/U.S.), v. 66, n. 4, Article 8, fev. 2015, p. 1776-1777.

17 QUEIJO, Maria Elizabeth. O direito de não produzir prova contra si mesmo: o princípio nemo tenetur se detegere e suas decorrências no processo penal. 2. ed. São Paulo: Saraiva, 2012, p. 208.

18 HAPNER, Andrew M. You have the right to remain silent, but anything you don't say may be used against you: the admissibility of silence as evidence after Salinas v. Texas. Florida Law Review, Gainesville (Florida/U.S.), v. 66, n. 4, Article 8, fev. 2015, p. 1776-1777.

19 Ibidem, p. 1766-1767. 
Na ausência dessas garantias, presume-se que a confissão foi obtida de forma coativa. ${ }^{20}$

A Corte Suprema norte-americana, no caso Doyle v. Ohio (1976), dispôs que qualquer silêncio ocorrido após as advertências de Miranda não serve nem como indício nem como prova. Contudo, o tema não foi abordado sob o enfoque do direito à não autoincriminação, mas sim do princípio do devido processo constante da Décima Quarta Emenda à Constituição do país. No caso Jenkins v. Anderson (1980), a Corte considerou que o silêncio pré-custódia e pré-Miranda pode ser indicado como indício, não violando o devido processo, já que os acusados renunciaram a algumas proteções constitucionais optando voluntariamente em declarar. ${ }^{21}$ No caso Salinas $v$. Texas (2013), a Corte Suprema norte-americana sustentou que o silêncio pré-custódia e pré-Miranda é admissível como prova material, a não ser que o acusado tenha invocado expressamente o privilégio contra a autoincriminação. ${ }^{22}$

Na América Latina, o tratamento ao direito à não autoincriminação é geralmente similar, porém bem mais protetivo do indivíduo do que nos Estados Unidos e no âmbito do TEDH. Normalmente abrange mais do que o simples direito de silenciar-se, admitindo-se inclusive a mentira, proscrevendo-se o juramento e proibindo-se obrigar o acusado a produzir prova contra si mesmo, ao menos na forma ativa, vedando-se o emprego de qualquer forma violenta ou coercitiva para se obter uma declaração.

No Peru, segundo o exposto por Miguel Ángel C. Bustos ${ }^{23}$, o direito à não autoincriminação protege, além do direito do imputado de guardar silêncio, o direito de declarar, elegendo o conteúdo da declaração, podendo declarar falsamente. Proíbe-se a utilização de tortura ou qualquer método violento ou coercitivo para se obter uma declaração.

20 KITAI-SANGERO, Rinat. Respecting the privilege against self-incrimination: a call for providing Miranda warnings in non-custodial interrogations. New Mexico Law Review, Albuquerque (U.S.), v. 42, 9 Dez. 2012, p. 204-207. Ibidem, p. 1767-1768.

BUSTOS, Miguel Ángel Caccha. El derecho a no autoincriminar-se en los procesos penales en el Distrito Judicial de Lima Sur, Tese para obter o título profissional de advogado - Facultad de Humanidades - Escuela Profesional de Derecho, Universidad Autónoma del Perú, Lima, 2016, p. 77-78. 
Norma Valeria T. Escobar ${ }^{24}$ esclarece que a Constituição Política Peruana não alberga nenhuma disposição expressa do direito à não autoincriminação. No entanto, a Corte Suprema entende que essa garantia constitui um conteúdo do direito ao devido processo, além de estar reconhecida expressamente em instrumentos internacionais de direitos humanos, dos quais o país é signatário. Esta garantia consiste no direito a não declarar culpado nem a ser obrigado a declarar contra si mesmo.

$\mathrm{Na}$ Argentina, sua Constituição ${ }^{25}$ estipula no art. 18 que: "Nadie puede ser obligado declarar contra sí mismo”. Além disso, o direito de não ser obrigado a declarar contra si mesmo, estipulado no art. $8^{\circ}$, 'g', da CADH, ostenta hierarquia constitucional, por força do art. 75, inciso 22, de sua Constituição.

A Corte Suprema da Argentina (CSJN), no caso "Agüero Corvalán” $(32: 2146)^{26}$, reafirmou entendimento anterior de que as declarações tomadas sob juramento do processado são contrárias ao direito constitucional de defesa em juízo e de que o juramento implica uma coação moral que invalida a declaração do imputado, pois trata-se de uma forma de obrigá-lo, eventualmente, a declarar contra si mesmo. No entanto, entendeu que a simples exortação legal de declarar conforme a verdade não significa o mesmo que declarar sob juramento ou promessa de dizer a verdade e por isso não infringe o disposto no art. 18 da Constituição. Só violaria esse direito constitucional se se tentasse ir além da referida exortação, coagindo ou ameaçando concretamente o imputado a declarar.

Conforme relata José Milton Peralta ${ }^{27}$, a Corte Suprema Argentina entende que o direito à não autoincriminação só protege as comunicações do imputado que deveriam provir de sua livre vontade, sendo proibidos

24 ESCOBAR, Norma Valeria Torres. El principio de no autoincriminación en el derecho procesal penal. Tese para obtenção do título de advogada - Carrera de Derecho - Facultad de Jurisprudencia, Universidad Regional Autónoma de los Andes - UNIANDES, Ibarra (Equador), 2014, p. 39-40.

25 Disponível em: <https://bibliotecadigital.csjn.gov.ar/Constitucion-de-la-Nacion-Argentina-Publicacion-del-Bicent.pdf>. Acesso em: 27 abr. 2018.

26 Disponível em: <https://sj.csjn.gov.ar/sj/tomosFallos.do?method=iniciar>. Acesso em: 27 abr. 2018.

27 PERALTA, José Milton. La no obligación de declarar contra uno mismo. In: RIVERA, Julio C. (h) et al. Tratado de los derechos constitucionales. Buenos Aires: Abeledo Perrot, 2014. v. 3. Cap. 4, p. 423. 
métodos violentos para obtenção de provas. Não abrange, porém, outras colaborações probatórias que possam prejudicá-lo.

José Luis Eloy M. Brand ${ }^{28}$ expõe que no México o direito à não autoincriminação engloba o direito a declarar e a manter-se em silêncio. $\mathrm{O}$ acusado tem o direito de ser informado desses direitos e de que tem direito de ser assistido por advogado. Não há exigência de juramento, podendo faltar com a verdade. É proibido qualquer método violento para obtenção de declaração. O exercício do direito de não declarar não pode ensejar presunção de culpabilidade, não pode gerar nenhum prejuízo ao acusado e não pode operar confissão ficta.

Juan David Riveros-Barragán ${ }^{29}$ descreve que na Colômbia o direito à não autoincriminação está previsto no artigo 33 da sua Constituição Política. Abarca o direito do acusado a declarar, podendo dar a sua versão dos fatos, o direito de não declarar, permanecendo calado, o direito de ser informado de que pode guardar silêncio e de que não é obrigado a declarar contra si mesmo. Não há dever de prestar juramento, a não ser que o imputado se ofereça a declarar. Neste caso, a Corte considera que se trata de mera formalidade legal prévia à declaração, mas da qual não se pode derivar consequências jurídicas penais adversas ao depoente quando sua declaração versar sobre sua própria conduta.

Javier W. Von Bernath ${ }^{30}$ informa que o direito à não autoincriminação está previsto na Constituição Política do Chile, no artigo 19, número 7, letra f. Afirma que naquele país, essa garantia compreende o direito de não ser obrigado a declarar e, se quiser declarar, não há obrigação de dizer a verdade, sendo vedado o juramento sobre fato próprio. Assevera que a lei consagra uma exortação de dizer a verdade. Porém o

28 BRAND, José Luis Eloy Morales. ¿Defensa o autoincriminación? Sobre la declaración del imputado en el sistema penal acusatorio. Redhes - Revista de Derechos Humanos y Estudios Sociales, San Luis Potosí (México), ano VI, n. 12, p. 123-144, jul.-dez. 2014, p. 133-138.

29 RIVEROS-BARRAGÁN, Juan David. El derecho a guardar silencio: visión comparada y caso colombiano. Revista Colombiana Derecho Internacional, Bogotá (Colômbia), n. 12, Ed. Especial, 2008, p. 381-384.

30 BERNATH, Javier Wilenmann Von. El tratamiento del autofavorecimiento del imputado. Sobre las consecuencias substantivas del principio de no autoincriminación. Revista de Derecho - Universidad Católica del Norte, Coquimbo (Chile), v. 23, n. 1, p. 111-139, jun. 2016, p. 112-113 e 120-121. 
sistema tende a eliminar as consequências decorrentes das obrigações de sinceridade. A mentira não induz crime de falso testemunho nem de obstrução da investigação.

De acordo com Angélica Marlene Y. Quinatoa ${ }^{31}$, o direito à não autoincriminação encontra amparo no art. 77 , numeral 7 , literal C, da Constituição Política do Equador. Lá essa garantia inclui o direito de não ser obrigado a declarar, podendo guardar silêncio; de declarar, inclusive falsamente, não se lhe exigindo o juramento; de ter assistência de advogado; de ser informado de seus direitos; de não sofrer coação ou tortura para se confessar; de não colaborar com a própria condenação e de não se confessar culpado.

A Constituição da República Federativa do Brasil de 1988 estabeleceu no inciso LXIII do art. $5^{\circ}$ que: "o preso será informado de seus direitos, entre os quais o de permanecer calado, sendo-lhe assegurada a assistência da família e de advogado"32. Tal dispositivo enseja interpretação extensiva, conforme entendimento da Suprema Corte brasileira (STF).

O STF compreende que o "privilégio" contra a autoincriminação pode ser invocado por qualquer pessoa, seja na condição de testemunha, de suspeito, indiciado, denunciado ou réu que deva prestar depoimento perante órgãos do Poder Legislativo, do Poder Executivo ou do Poder Judiciário. O exercício do direito ao silêncio não pode implicar qualquer restrição à esfera jurídica daquele que regularmente o invocou. Ninguém pode ser tratado como culpado antes de uma decisão condenatória definitiva. É o que se verifica no julgamento do Habeas Corpus 79.812/SP ${ }^{33}$.

No Habeas Corpus 99.289/RS ${ }^{34}$, o STF consignou que o exercício do direito ao silêncio não implica confissão e não pode causar nenhum

31 QUINATOA, Angélica Marlene Yugcha. El garantismo constitucional frente al principio de legalidad y el derecho a la no incriminación en el procedimiento abreviado en la legislación penal ecuatoriana. Tese para obtenção do título de advogada - Escuela de Derecho - Facultad de Jurisprudencia, Ciencias Políticas y Sociales, Universidad Central del Ecuador, Quito, jun. 2014, p. 3 e 71-74.

32 Disponível em: <http://www.planalto.gov.br/ccivil_03/constituicao/constituicaocompilado.htm>. Acesso em: 27 abr. 2018.

33 STF, HC 79.812/SP, Relator Min. Celso de Mello, Tribunal Pleno, j. 08/11/2000.

34 STF, HC 99.289/RS, Relator Min. Celso de Mello, 2a Turma, j. 23/06/2009. 
prejuízo ao acusado. No julgamento do HC 94.601/CE ${ }^{35}$, a Corte Suprema dispôs que o interrogatório do réu é um meio de defesa, que compõe o devido processo legal.

Segundo o entendimento do STF esposado no julgamento da Medida Cautelar no Habeas Corpus 96.219/SPº, a participação do acusado na colaboração para a apuração de crimes contra si é facultativa. A "prerrogativa" de permanecer em silêncio vai além do direito de não colaborar, oralmente, com a investigação criminal. Abrange também o direito de o indivíduo não produzir prova contra si mesmo; o direito a se recusar a participar, ativa ou passivamente, de procedimentos probatórios que lhe possam afetar a esfera jurídica, como reprodução simulada dos fatos delituosos investigados. Também não lhe é obrigado fornecer padrões gráficos para fins de perícia criminal.

Registra-se que essa interpretação extensiva dada pelo STF se limita aos fatos criminosos imputados ao indivíduo, não abrangendo a sua qualificação, conforme disposto no julgamento do Recurso Extraordinário RE 640.139/DF ${ }^{37}$ de reconhecida repercussão geral. Assim, o acusado não tem o direito de silenciar ou mentir quanto aos dados pessoais que o qualifiquem, como nome, sexo, estado civil, filiação, idade e outros.

Apesar desse entendimento tão ampliativo quanto ao direito à não autoincriminação, a Corte Suprema brasileira se afasta do entendimento da Corte Interamericana de Direitos Humanos (Corte IDH) no âmbito da CADH com relação à teoria das nulidades. Enquanto esta considera decorrer prejuízo do simples desrespeito ao direito ao silêncio, aquela restringe esse direito, exigindo demonstração de prejuízo pelo réu quando o direito foi desrespeitado, deixando ao livre arbítrio do julgador o que considera ser ou não prejuízo. ${ }^{38}$

35 STF, HC 94.601/CE, Relator Min. Celso de Mello, 2a Turma, j. 04/0/2009. STF, HC 96.219 MC/SP, Decisão Monocrática Min. Celso de Mello, j. 09/10/2008. STF, RE 640.139 RG/DF, Relator Min. Dias Toffoli, Tribunal Pleno, j. 22/09/2011. GUEDES, Gabriel Pinto. O direito a não produzir prova contra si mesmo: aproximações entre os cases da Corte Interamericana de Direitos Humanos e do Supremo Tribunal Federal. Dissertação (Mestrado) - Programa de Pós-Graduação em Ciências Criminas, Pontifícia Universidade Católica do Rio Grande do Sul, Porto Alegre, 2014, p. 16. 


\section{Fundamentos do diREITO À NÃo AUTOINCRIMINAÇÃo}

Como visto, o direito à não autoincriminação é um direito humano e fundamental, pois previsto em Tratados e Convenções Internacionais de Direitos Humanos e na Constituição do país. É, assim, relevante a ponderação de José Milton Peralta ${ }^{39}$ de que o fato desse direito ocupar essa posição normativa privilegiada constitui seu fundamento legal, mas não o seu fundamento primordial. A norma não pode justificar-se em si mesma. A razão por que esse direito toma esse lugar privilegiado, ou seja, o motivo por que ele existe é que constitui o seu fundamento central.

Verifica-se que não há na literatura jurídica ampla discussão sobre o fundamento central do direito à não autoincriminação. A bibliografia sobre o tema apresenta conceitos, objetivos, origens históricas e consequências. No entanto, raramente se encontra análise profunda sobre o fundamento principal.

Na bibliografia pesquisada, encontraram-se várias razões apontadas como justificadoras do direito à não autoincriminação, dentre elas, a dificuldade humana em confessar seus próprios erros, o sistema acusatório, a presunção de inocência, o direito de defesa e a coibição de tortura para se obter uma confissão. A tutela da dignidade humana foi o fundamento mais assinalado. Quanto a este aspecto, encontrou-se a indicação da integridade física e mental, da intimidade, da liberdade de autodeterminação e de consciência, da autopreservação e da liberdade moral.

Marcelo S. Albuquerque ${ }^{40}$ defende que o direito à não autoincriminação tem três fundamentos: histórico, natureza humana e processual. O fundamento histórico seria o desestímulo à obtenção forçada de confissão, pois esse direito surgiu em resposta às barbáries cometidas contra os acusados, que eram frequentemente submetidos à tortura, a fim de lhes extrair uma confissão, considerada àquela época a rainha das provas.

Diz o autor que a natureza humana revela que o homem tem dificuldades em espontaneamente confessar suas próprias falhas e assumir

39 PERALTA, José Milton. La no obligación de declarar contra uno mismo. In: RIVERA, Julio C. (h) et al. Tratado de los derechos constitucionales. Buenos Aires: Abeledo Perrot, 2014. v. 3. Cap. 4, p. 400.

40 ALBUQUERQUE, Marcelo Schirmer. A garantia de não auto-incriminação: extensão e limites. Belo Horizonte: Del Rey, 2008, p. 69. 
as consequências que delas possam advir. Aqui o fundamento na natureza humana seria a garantia da integridade mental do indivíduo, de sua liberdade de autodeterminação e de consciência. Afirma, ainda, que este direito consiste em um meio de efetivar o direito de ampla defesa. Assim, tem também fundamento processual. ${ }^{41}$

$\mathrm{O}$ autor assevera que a tentativa de extrair à força palavras de alguém que não queira falar é atentatório à sua dignidade, mesmo que não se trate de força física, como uma norma cogente que atribui alguma consequência negativa ao silêncio. É natural no homem a proteção de sua liberdade de consciência e o seu instinto de autopreservação. Por isso a garantia de não autoincriminação proscreve o juramento e certos métodos de interrogatórios, dentre eles o soro da verdade e o detector de mentiras. ${ }^{42}$

Como consequência desses fundamentos apontados, Marcelo S. Albuquerque $^{43}$ defende que só cabe a aplicação do direito à não autoincriminação quando houver necessidade de se atender às suas finalidades: desestimular a obtenção forçada de confissão, garantir a ampla defesa, proteger direitos fundamentais que compõem a dignidade da pessoa humana, como a integridade física e mental, a liberdade de autodeterminação e de consciência. Não é um direito absoluto. Exige-se sempre a observância da proporcionalidade. Ampara-se somente o direito a não declarar verbalmente contra si mesmo, bem como a não participar de acareação nem de reconstituição simulada dos fatos, já que violam a dignidade humana. Não confere ao indivíduo uma liberdade ampla de não colaborar na produção probatória contra si nem lhe concede o direito de mentir, embora não seja crime a mentira.

Guilherme G. Walcher ${ }^{44}$ segue a mesma linha que Marcelo S. Albuquerque. Sustenta que o fundamento do princípio da não autoincriminação é a tutela da integridade física e mental do indivíduo. Funda-se

41 Ibidem, p. 69.

42

43

Ibidem, p. 72-73.

Ibidem, p. 52-53 e 91-93.

WALCHER, Guilherme Gehlen. A garantia contra a autoincriminação no Direito brasileiro: breve análise da conformação do princípio nemo tenetur se detegere à luz da jurisprudência nacional e estrangeira. Revista de Doutrina da $4^{a}$ Região, Porto Alegre, n. 57, 18 dez. 2013, [s/p]. 
também no reconhecimento da dificuldade, inerente à natureza humana, de confessar erros, desvios de conduta e principalmente delitos. Além disso, veio como uma retaliação às atrocidades cometidas na Idade Média, em que se utilizava tortura para obtenção de uma confissão.

Como consequência dessa fundamentação, o acusado é protegido de ser obrigado, por meio de fraude ou coação, física ou moral, a produzir prova contra si mesmo, porém não de forma ampla. Tem apenas o direito a não colaborar com as investigações de forma ativa na modalidade oral, ou seja, não declarar e não se confessar. Contudo, o dever das partes de colaborar com a Justiça na apuração dos fatos em tese delituosos, como as exigências de apresentação de documentos e de submissão a intervenções corporais que não ensejam risco de morte ou à saúde, somente a Constituição e a lei podem determinar. ${ }^{45}$

Para Guilherme G. Walcher ${ }^{46}$, o direito à não autoincriminação não concede ao indivíduo um direito à mentira. Diz que esta tem um grau de reprovabilidade muito maior do que o silêncio. Ela apenas é tolerada pelo ordenamento jurídico quando imprescindível para viabilizar o direito de autodefesa, com o intuito de elidir a responsabilização criminal, exigindo-se, no entanto, a razoabilidade e a proporcionalidade.

Carlos Henrique B. Haddad ${ }^{47}$ não discute o fundamento central do princípio contra a autoincriminação. No entanto, indica sua extensão. Afirma que esse direito abrange a vedação de obrigar a se confessar, a proibição do juramento e o direito de permanecer calado. Garante a liberdade de declaração do acusado, abarcando todas as ações que possam contribuir para a autoincriminação, orais ou físicas, e não se pode dele exigir a colaboração na produção de provas incriminadoras. A inércia do acusado não implica assunção de culpa. Somente os atos que dependem da vontade do indivíduo estão protegidos. Portanto, não se aplica aos atos que constituem mera tolerância do acusado, nem às condutas comissivas destinadas a evitar a produção, por terceiros, de prova desfavorável.

${ }^{45}$ Ibidem, [s/p].

${ }^{46}$ Ibidem, [s/p].

47 HADDAD, Carlos Henrique Borlido: Conteúdo e contornos do princípio contra a auto-incriminação. Tese de Doutorado - Faculdade de Direito da Universidade Federal de Minas Gerais, Belo Horizonte, 2003, p. 299-230. 
O fundamento central do direito à não autoincriminação também não é indicado por Miguel Ángel C. Bustos ${ }^{48}$. Todavia afirma que se trata de uma manifestação do direito de defesa, do devido processo legal e do princípio da presunção de inocência. Destaca que essa garantia não está adstrita somente ao âmbito do direito penal, mas se estende a todo procedimento que implique uma sanção. Acresce que em um Estado Constitucional de Direito, todos os envolvidos na persecução penal devem entender claramente que o fato de o imputado silenciar ou se contradizer em suas declarações não gera indício de culpabilidade, significando tão-somente que ele está exercendo seu direito a não se autoincriminar. Esse direito não protege somente o direito de guardar silêncio, mas alcança a escolha do conteúdo da declaração, não estando vinculada à verdade. Por isso, é vedado o juramento, bem como a prática de qualquer violência para se obter uma declaração.

Víctor Moreno Catena ${ }^{49}$, apesar de não examinar de modo específico o fundamento principal do direito à não autoincriminação, deixa a entender que seria o princípio da presunção de inocência, o qual veda uma condenação em que não haja convicção de culpabilidade. O acusado deve ser tratado como inocente enquanto não for condenado num processo devidamente legal. Dessa forma, o indivíduo não pode ser obrigado a declarar ou a colaborar com a investigação.

Sustenta o autor que o direito à não autoincriminação é um direito incondicional, ou seja, seu uso não pode acarretar qualquer consequência jurídica prejudicial ao acusado. Suas declarações têm natureza de ato de defesa. Assim, o acusado tem que ser previamente informado sobre os seus direitos: de ser assistido por um advogado; de saber sobre os fatos que lhe são imputados; de não declarar contra si mesmo e de não se confessar culpado; de optar por não declarar ou por declarar, ainda que seja parcialmente; e de saber sobre as consequências que poderão advir de suas declarações. ${ }^{50}$

48 BUSTOS, Miguel Ángel Caccha. El derecho a no autoincriminar-se en los procesos penales en el Distrito Judicial de Lima Sur, Tese para obter o título profissional de advogado - Facultad de Humanidades - Escuela Profesional de Derecho, Universidad Autónoma del Perú, Lima, 2016, p. 77-78.

49 CATENA, Víctor Moreno. Sobre o princípio da presunção de inocência. Revista CEJ, Brasília, ano XIX, n. 67, p. 101-111, set.-dez. 2015, p. 108-109.

50 Ibidem, p. 109-110. 
Caroline Araújo ${ }^{51}$ igualmente não aponta o fundamento central do direito à não autoincriminação. Assegura que é um direito fundamental previsto na Constituição, inerente ao sistema acusatório, além de ser uma garantia processual. Como consequência desse direito tem-se, além do direito ao silêncio, o direito de não colaborar na produção de provas contra si. Alega que tem influência nos princípios da dignidade da pessoa humana, do devido processo legal, do contraditório e da ampla defesa.

Norma Valeria T. Escobar ${ }^{52}$ assevera que o fundamento do direito à não autoincriminação é a dignidade da pessoa humana ao ser reconhecido o acusado como sujeito e não como mero objeto de prova. Coagir o acusado, exigindo-lhe uma declaração que exteriorize um conteúdo de admissão de culpabilidade ou de confissão, viola sua liberdade moral e, portanto, sua dignidade. Desse fundamento resulta que do exercício desse direito não podem derivar consequências negativas para seu titular. O silêncio do acusado não pode ser considerado sequer um indício de culpabilidade.

A autora diz que o direito à não autoincriminação se revela no direito de autodefesa e na presunção de inocência. Atribui-se exclusivamente ao Estado-acusador a carga probatória e se proíbe a utilização no processo de provas irregularmente obtidas ${ }^{53}$. Infere-se, pois, que o direito de autodefesa, a presunção de inocência e a inadmissibilidade de provas ilícitas são decorrências do direito à não autoincriminação.

Maria Elizabeth Queijo ${ }^{54}$ compreende que o direito fundamental à não autoincriminação se traduz numa esfera de liberdade do indivíduo frente ao Estado, que não se reduz ao direito ao silêncio. Visa proteger o indivíduo contra os abusos utilizados na persecução penal,

51 ARAÚJO, Caroline. O princípio do nemo tenetur se detegere no crime de embriaguez ao volante: pièce de résistance no vale tudo probatório. Dissertação (Mestrado - Programa de Pós-Graduação em Ciências Criminais), Pontifícia Universidade Católica o Rio Grande do Sul, Porto Alegre, 2015, [s/p].

52 ESCOBAR, Norma Valeria Torres. El principio de no autoincriminación en el derecho procesal penal. Tese para obtenção do título de advogada - Carrera de Derecho - Facultad de Jurisprudencia, Universidad Regional Autónoma de los Andes - UNIANDES, Ibarra (Equador), 2014, p. 30-36.

Ibidem, p. 30-36.

QUEIJO, Maria Elizabeth. O direito de não produzir prova contra si mesmo: o princípio nemo tenetur se detegere e suas decorrências no processo penal. 2 . ed. São Paulo: Saraiva, 2012, p. 77. 
abrangendo a proteção "contra violências físicas e morais, empregadas para compelir o indivíduo a cooperar na investigação e apuração de delitos, bem como contra métodos proibidos de interrogatório, sugestões e dissimulações”.

Para a autora, a dignidade é da essência da natureza humana e é ela o fundamento do direito à não autoincriminação, exigindo preservação da integridade física e moral do acusado. Consequentemente, o investigado não pode ser obrigado a dizer a verdade nem a colaborar na produção da prova, nem poderá ser submetido a tortura ou a tratamento desumano ou degradante ou a qualquer outra medida que seja prejudicial à sua integridade física e moral. ${ }^{55}$

Marcia C. D. Yokoyama ${ }^{56}$ igualmente entende que o direito à não autoincriminação encontra fundamento na dignidade da pessoa humana. Trata-se de "manifestação do direito à intimidade, de preservação, de escolha entre falar ou calar, de não se expor, do livre exercício da consciência”. Acrescenta que silenciar para não se prejudicar advém da natureza humana.

A autora aduz que a dignidade humana é um supraprincípio que dá fundamento a todos os direitos fundamentais. O direito à não autoincriminação daí decorrente se traduz num direito de defesa do indivíduo perante o Estado, o qual deverá adotar um comportamento negativo, uma postura de abstenção, devendo respeitar a autodeterminação da pessoa de abster-se de falar em interrogatórios ou em fase anterior. Logo, o silêncio do acusado não pode lhe gerar qualquer desvantagem na persecução penal. ${ }^{57}$

Para a autora, a presunção de inocência, o devido processo legal, a ampla defesa e o contraditório, a informação prévia acerca do direito e a proibição de provas ilícitas são meios que possibilitam a efetivação da garantia de não autoincriminação. Pela presunção de inocência o acusado não precisa falar para demonstrar sua inocência. Pelo devido

\footnotetext{
55 Ibidem, p. 97, 102 e 113.

56 YOKOYAMA, Marcia Caceres Dias. O direito ao silêncio no interrogatório. Dissertação (Mestrado) Pontifícia Universidade Católica de São Paulo, São Paulo, 2007, p. 106 e 144.

57 Ibidem, p. 46-50.
} 
processo legal, garante-se o contraditório e a ampla defesa, assegurando ao acusado a informação acerca da imputação, das suas consequências e da oportunidade de defesa. Pelo silêncio ou a apresentação da sua versão dos fatos, o acusado exerce a opção pela atitude que lhe seja mais conveniente em sua defesa. ${ }^{58}$

Rochester O. Araújo ${ }^{59}$ não analisa especificamente o fundamento do direito à não autoincriminação. Entretanto, pode-se extrair de sua explanação que a razão seria o instinto de autopreservação do sujeito e a sua capacidade de autodeterminação, já que ela alega que esses são os dois bens jurídicos objeto de proteção daquele direito.

A autora acrescenta que tal direito configura essencialmente em uma regra quanto às provas no processo penal e, por isso, seu respeito exige critérios pré-fixados, incluindo o direito de informação prévia do acusado, o respeito à sua voluntariedade na participação da prova e o acompanhamento por defensor técnico ${ }^{60}$. Deduz-se, então, que essas são formas de se possibilitar a efetivação do direito à não autoincriminação.

José Milton Peralta ${ }^{61}$ sustenta que há dois fundamentos para o direito à não autoincriminação. Um deles é a inaceitável imoralidade de se colocar o imputado frente a disjuntivas indesejáveis: "calar e receber uma consequência negativa por calar ou falar e, neste caso, ter uma consequência negativa ou por dar falso testemunho ou por se autoincriminar". Chamam-se essas disjuntivas de "trilema”. O cerne da questão é evitar que se exija do imputado que colabore em um processo contra si, pois isto é imoral. O outro fundamento, complementar ao primeiro, está ligado à necessidade de assegurar ao imputado o exercício do direito de defesa sem temores, inclusive facultando-lhe a mentira.

58 Ibidem, p. 53-75 e 144-145.

59 ARAÚJO, Rochester Oliveira. O direito fundamental contra a autoincriminação: a análise a partir de uma teoria do Processo Penal Constitucional. Dissertação (Mestrado em Constituição e Garantias de Direitos), Universidade Federal do Rio Grande do Norte, Natal, 2013, p. 178-194.

60 Ibidem, p. 13-18.

61 PERALTA, José Milton. La no obligación de declarar contra uno mismo. In: RIVERA, Julio C. (h) et al. Tratado de los derechos constitucionales. Buenos Aires: Abeledo Perrot, 2014. v. 3. Cap. 4, p. 407-416. (livre tradução) 
Ainda que o método utilizado para obter declarações não seja em si incorreto ou reprovável, é moralmente inaceitável colocar o imputado frente a essas disjuntivas desagradáveis ${ }^{62}$. Por exemplo, a utilização do soro da verdade, de detector de mentiras ou da hipnose, a exigência de juramento de dizer a verdade, previsão e aplicação de sanção legal para o silêncio, etc.

Quanto à mentira, José Milton Peralta ${ }^{63}$ não se mostra suficientemente claro. Ora afirma que a faculdade de mentir é um fundamento do direito à não autoincriminação, ligado à necessidade de assegurar ao imputado o exercício do direito de defesa sem temores. Ora diz que não seria um fundamento, pois a opção pelo silêncio já libera o imputado de qualquer dilema moral ou prudencial.

A principal decorrência do fundamento central do direito à não autoincriminação apresentada por José Milton Peralta ${ }^{64}$ é que ocorre violação desse direito em duas situações: quando o imputado é coagido a declarar e também quando se infere qualquer conclusão incriminatória em razão do seu silêncio. Seja através de presunção de culpabilidade absoluta ou relativa, seja quando se considera o silêncio como um mero indício, o indivíduo se sente frente a disjuntivas desagradáveis, que formam o chamado "trilema".

Embora seja incontroverso o direito ao silêncio em seu sentido estrito de não declarar e não se confessar culpado, Maria Elizabeth Queijo ${ }^{65}$ constata que ainda há uma relutância de muitos magistrados em conferir efetividade ao exercício desse direito. Nas sentenças condenatórias fazem inferência negativa ao silêncio, justificando-se que há no processo outras provas que por si só comprovam o delito. Argumentam que esta postura só interessaria a um culpado; se inocente, teria ele todo o interesse em responder ao interrogatório, já que normalmente sua conduta seria de protestar reiteradamente por sua inocência.

\footnotetext{
62 Ibidem, p. 409.

63 Ibidem, p. 410 e 416.

64 Ibidem, p. 409-410.

65 QUEIJO, Maria Elizabeth. O direito de não produzir prova contra si mesmo: o princípio nemo tenetur se detegere e suas decorrências no processo penal. 2. ed. São Paulo: Saraiva, 2012, p. 155-156.
} 
No entanto, esses argumentos dos magistrados são infundados, inconsistentes. Como explica Marcelo Sancinetti ${ }^{66}$, aquele "trilema" que justifica o direito de não declarar contra si mesmo está pensado justamente para as hipóteses em que o interrogado é culpado, já que se pretende evitar que ele seja colocado ante aquelas disjuntivas desagradáveis, pois é justamente aí que é imoral obrigá-lo a declarar.

De fato, se o interrogado for inocente, a imposição de uma declaração em nada afetaria sua integridade, pois não haveria falhas, erros ou desvios para assumir. No entanto, se for culpado e obrigado a declarar, das duas uma: ou mentirá ou irá se autoincriminar. Aí é que sua integridade mental e moral estará violada, já que vai contra sua dignidade, sua natureza humana. Entretanto, admitir que há grande probabilidade de culpa do acusado que silencia não permite lhe atribuir consequências negativas, já que o exercício de um direito não autoriza prejudicar o seu titular.

\section{AnÁlise dos ARgumentos apresentados}

Pela análise das exposições acima, constata-se que são vários os fundamentos indicados para o direito à não autoincriminação. De igual forma, são diversas as consequências apontadas como sua decorrência. Percebe-se que há uma confusão entre o fundamento do direito com aquilo que decorre dele ou que seja um dos meios de possibilitar sua efetivação. Deve-se considerar, entretanto, que fundamento central é o motivo ensejador da existência do direito.

Afirmar que algo é o fundamento central do direito à não autoincriminação significa dizer que este nasceu por causa daquilo. O sistema acusatório, a presunção de inocência, a ampla defesa e a coibição da tortura são fundamentos apontados, todavia, carentes de argumentos sólidos.

A estrutura do sistema acusatório e a presunção de inocência como fundamento do princípio da não autoincriminação é justificada no

\footnotetext{
66 SANCINETTI, Marcelo. El delito de enriquecimiento ilícito de funcionario público - art. 268, 2, C.P. 2. ed. Buenos Aires: Ad-Hoc, 2000, p. 44 e ss. apud PERALTA, José Milton. La no obligación de declarar contra uno mismo. In: RIVERA, Julio C. (h) et al. Tratado de los derechos constitucionales. Buenos Aires: Abeledo Perrot, 2014. v. 3. Cap. 4, p. 408-409.
} 
fato de que no sistema acusatório, o acusado tem presumida sua inocência e, por isso, o ônus probatório fica totalmente a cargo do Estado.

José Milton Peralta ${ }^{67}$ afirma ser insatisfatório esse argumento, alegando que, se fosse válido, o Estado-acusador, que tem o ônus probatório, não poderia exigir a colaboração de terceiros, como testemunhas, que são obrigadas a declarar o que sabem a respeito do ocorrido e a dizer a verdade. Da mesma forma, a confissão voluntária do acusado retiraria sua presunção de inocência e, então, o Estado-acusador não mais necessitaria provar a acusação, o que não acontece.

O sistema acusatório constitui-se num conjunto de princípios e regras que disciplinam a persecução penal. De acordo com Luigi Ferrajoli ${ }^{68}$, o modelo acusatório se caracteriza, principalmente, por uma separação rígida entre juiz e acusação, paridade entre acusação e defesa, publicidade e oralidade do julgamento. O juiz é um sujeito passivo e rigorosamente separado das partes. A acusação inicia o debate paritário e detém o ônus probatório. O processo se desenvolve mediante um contraditório público e oral.

A promoção da segurança pública, investigando os delitos e punindo os culpados, mas ao mesmo tempo garantindo aos indivíduos a preservação de todos os seus direitos humanos, inclusive o direito de não se autoincriminar, é o objetivo do sistema acusatório. O direito à não autoincriminação não nasceu em razão deste sistema, sendo apenas um dos direitos que o compõem. Portanto, o sistema acusatório não é o fundamento ensejador da existência do direito à não autoincriminação.

A presunção de inocência é uma garantia do indivíduo de não ser considerado culpado enquanto não houver uma condenação definitiva após o trâmite de um devido processo legal. É também uma das garantias que compõem o sistema acusatório. A presunção de inocência corresponde mais apropriadamente a um dos meios que possibilitam a efetivação do direito à não autoincriminação do que a razão de sua existência. Como não se pode presumir culpado o indivíduo que se silencia ou que mente,

67 PERALTA, José Milton. La no obligación de declarar contra uno mismo. In: RIVERA, Julio C. (h) et al. Tratado de los derechos constitucionales. Buenos Aires: Abeledo Perrot, 2014. v. 3. Cap. 4, p. 406.

68 FERRAJOLI, Luigi. Direito e razão: teoria do garantismo penal. Tradução de Ana Paula Zomer Sica et al., 3. ed., São Paulo: Revista dos Tribunais, 2010, p. 518-520. 
então ele se sente mais livre para decidir se declara ou não. Contudo, ainda que o réu confessasse espontânea e conscientemente, renunciando ao direito à não autoincriminação, a presunção de inocência perduraria até a condenação definitiva.

A coibição da tortura e de outros meios violentos para obtenção de uma declaração autoincriminante também é apresentada como fundamento do direito à não autoincriminação. Certamente, o reconhecimento dessa garantia tem grande relevância na coibição da utilização de tortura para a obtenção de uma confissão, tão aplicada na Idade Média e repelida pelo sistema acusatório. Contudo esse direito existe independentemente de sua utilização.

A tortura constitui um mal em si mesma, sendo rechaçada qualquer que seja o emprego que se faça dela, sendo prevista como crime no ordenamento jurídico (Lei n. 9.455/199769). Trata-se de um meio aviltante da dignidade humana, pela imposição de sofrimento físico ou psíquico para se alcançar um fim. Contudo, como aponta Maria E. Quei$\mathrm{jo}^{70}$, o indivíduo não é obrigado a se autoincriminar independentemente do meio empregado, seja a tortura, seja meio astucioso ou enganador, seja método em que haja subjugação da vontade, como hipnose, soro da verdade e polígrafo.

Como bem argumenta José Milton Peralta ${ }^{71}$, a tortura é censurada não só quando utilizada para obter declarações autoincriminantes, mas em qualquer caso, seja para declarações autoincriminantes ou descriminantes, seja para declarações feitas por suspeitos ou não, ou ainda para declarações que buscam incriminar outras pessoas. Complementa dizendo que, se a razão do princípio da autoincriminação fosse elidir a tortura como meio de obtenção de prova, bastaria uma lei que simplesmente proibisse métodos violentos de obtenção de provas em geral.

69 Disponível em: <http://www.planalto.gov.br/ccivil_03/leis/19455.htm>. Acesso em 27 abr. 2018.

70 QUEIJO, Maria Elizabeth. O direito de não produzir prova contra si mesmo: o princípio nemo tenetur se detegere e suas decorrências no processo penal. 2. ed. São Paulo: Saraiva, 2012, p. 271-273.

71 PERALTA, José Milton. La no obligación de declarar contra uno mismo. In: RIVERA, Julio C. (h) et al. Tratado de los derechos constitucionales. Buenos Aires: Abeledo Perrot, 2014. v. 3. Cap. 4, p. 404-405. 
A dignidade humana é a mais indicada como fundamento do direito à não autoincriminação. De fato, é ela que, em última análise, embasa todos os direitos fundamentais. No entanto, cada direito fundamental visa proteger um ou alguns aspectos em particular da dignidade humana, como a integridade física, a integridade mental, a liberdade de autodeterminação, a liberdade moral, a liberdade de consciência, a autopreservação, a intimidade, dentre outros.

Dizer genericamente que a dignidade humana é o fundamento do direito à não autoincriminação não está incorreto, porém não delimita suficientemente qual é o aspecto particularizado que se visa proteger.

Quanto ao elemento particular da dignidade humana que fundamenta o direito à não autoincriminação, Marcelo S. Albuquerque ${ }^{72}$ aponta a liberdade de consciência e de autodeterminação, o instinto de autopreservação e a integridade física e mental do indivíduo. Marcia C. D. Yokoyama ${ }^{73}$ assinala a liberdade de consciência, a autopreservação e a intimidade. Rochester O. Araújo ${ }^{74}$ indica o instinto de autopreservação e a capacidade de autodeterminação do indivíduo. Norma Valeria T. Escobar $^{75}$ aponta a liberdade moral.

José Milton Peralta ${ }^{76}$ também afirma que o que se quer proteger com o direito à não autoincriminação é a dignidade humana, delimitada na integridade mental e moral do indivíduo. O autor vai um pouco mais além, pois determina exatamente o que viola a integridade mental e moral

72 ALBUQUERQUE, Marcelo Schirmer. A garantia de não auto-incriminação: extensão e limites. Belo Horizonte: Del Rey, 2008, p. 52-53 e 72-73.

73 YOKOYAMA, Marcia Caceres Dias. O direito ao silêncio no interrogatório. Dissertação (Mestrado em Direito) - Pontifícia Universidade Católica de São Paulo, São Paulo, 2007, p. 144.

74 ARAÚJO, Rochester Oliveira. O direito fundamental contra a autoincriminação: a análise a partir de uma teoria do Processo Penal Constitucional. Dissertação (Mestrado em Constituição e Garantias de Direitos), Universidade Federal do Rio Grande do Norte, Natal, 2013, p. 178-194.

75 ESCOBAR, Norma Valeria Torres. El principio de no autoincriminación en el derecho procesal penal. Tese para obtenção do título de advogada - Carrera de Derecho - Facultad de Jurisprudencia, Universidad Regional Autónoma de los Andes - UNIANDES, Ibarra (Equador), 2014, p. 30-36.

76 PERALTA, José Milton. La no obligación de declarar contra uno mismo. In: RIVERA, Julio C. (h) et al. Tratado de los derechos constitucionales. Buenos Aires: Abeledo Perrot, 2014. v. 3. Cap. 4, p. 407-416 e 438. 
do indivíduo: ser colocado frente a possíveis disjuntivas desagradáveis, que compõem o chamado "trilema", que se constitui na possibilidade de dar origem a consequências negativas, seja por optar por manter-se em silêncio ou por declarar, e, neste caso, por se autoincriminar ou por mentir, mesmo que o método utilizado para obter declarações não seja em si incorreto.

Parece também plausível a indicação de Marcelo S. Albuquerque ${ }^{77}$ e de Guilherme G. Walcher ${ }^{78}$ da integridade mental e moral do indivíduo, como um aspecto particular da dignidade humana, delimitada na dificuldade, inerente à natureza humana, de espontaneamente confessar suas próprias falhas, erros, desvios de conduta e assumir as consequências que possam advir dessas condutas.

Maria E. Queijo ${ }^{79}$ igualmente defende que a dignidade, que é da essência da natureza humana, é o fundamento do direito à não autoincriminação, exigindo preservação da integridade física e moral do acusado. Marcia C. D. Yokoyama ${ }^{80}$ entende que, como é da natureza humana silenciar-se para não se prejudicar, o direito à não autoincriminação encontra fundamento na dignidade da pessoa humana, como proteção da intimidade, da preservação, da escolha entre falar ou calar, de não se expor, do livre exercício da consciência.

É exatamente essa natureza humana que torna desagradáveis aquelas disjuntivas do chamado "trilema". Pois obrigar alguém a se autoincriminar, a admitir uma má conduta, uma falha, um desvio, é constrangê-lo. Sendo obrigado a declarar ou a dizer a verdade, terá que agir contrariamente à sua natureza. Isso atenta contra a sua

77 ALBUQUERQUE, Marcelo Schirmer. A garantia de não auto-incriminação: extensão e limites. Belo Horizonte: Del Rey, 2008, p. 69.

78 WALCHER, Guilherme Gehlen. A garantia contra a autoincriminação no Direito brasileiro: breve análise da conformação do princípio nemo tenetur se detegere à luz da jurisprudência nacional e estrangeira. Revista de Doutrina da $4^{a}$ Região, Porto Alegre, n. 57, 18 dez. 2013, [s/p].

QUEIJO, Maria Elizabeth. O direito de não produzir prova contra si mesmo: o princípio nemo tenetur se detegere e suas decorrências no processo penal. 2. ed. São Paulo: Saraiva, 2012, p. 97 e 102.

80 YOKOYAMA, Marcia Caceres Dias. O direito ao silêncio no interrogatório. Dissertação (Mestrado) Pontifícia Universidade Católica de São Paulo, São Paulo, 2007, p. 106 e 144. 
integridade mental e moral, que compõem a dignidade humana. Se o modo para se obrigar a declarar for violento, atenta também contra a integridade física.

Lembra-se que todos os direitos humanos são imanentes à natureza humana. São inerentes ao homem enquanto homem, que tem uma natureza, ou seja, uma essência como tal. Todo e cada homem possui uma natureza que é comum a todo ser humano. Por isso, tais direitos se revestem de caráter fundamental. ${ }^{81}$ Ademais, falar em dignidade humana, o princípio motriz de todos os direitos humanos, é admitir que ela é inerente ao ser humano, à sua essência, à sua natureza ${ }^{82}$. Os direitos humanos são direitos pré-existentes ao homem, que pertencem a este por sua natureza, já que do contrário seria admitir que seriam bens a que se aspiram e, assim, a serem conquistados por ainda não os possuir ${ }^{83}$.

Constitui, pois, fundamento central do direito à não autoincriminação a natureza humana, que tem dificuldade em espontaneamente confessar suas próprias falhas, erros, desvios de conduta e assumir as consequências que possam advir dessas condutas. Forçar o ser humano a agir contra essa natureza viola sua integridade mental e moral ou até física, se o meio for violento. Transgride aquela natureza humana e, portanto, a dignidade da pessoa humana colocar alguém frente a disjuntivas desagradáveis, constituídas da possibilidade de dar origem a consequências negativas, seja por optar por manter-se em silêncio ou por declarar, e, neste caso, por se autoincriminar ou por mentir.

Portanto, o fundamento do direito à não autoincriminação é mais bem delimitado conjugando estes três fatores interligados: o "trilema", a natureza humana e a integridade mental e moral do indivíduo. Levando-se em conta a natureza humana, tem-se violada a sua integridade mental e moral quando colocado frente àquelas disjuntivas desagradáveis. Essa é a razão de existência do direito à não autoincriminação.

81 BIDART CAMPOS, Germán J. Teoría general de los derechos humanos. Edición al cuidado de Miguel López Ruiz. Ciudad de México: Universidad Nacional Autónoma de México, 1989, p. 14-15.

82 Ibidem, p. 86.

83 BEUCHOT, Mauricio; JAVIER, Saldaña. Derechos humanos y naturaleza humana. Ciudad de México: Universidad Nacional Autónoma de México, 2000, p. 63. 
O fundamento do direito à não autoincriminação reflete em sua enorme relevância como garantia processual penal. Encontra-se severamente imbricado com outros princípios, tornando-os interdependentes. Dentre esses princípios, destaca-se o da presunção de inocência, que por sua vez impõe ao Estado o ônus probatório, reforçando o direito de não contribuir com a acusação na atividade probatória e evitando que a confissão seja supervalorada e buscada a todo custo. Também se encontra intimamente relacionado ao princípio da ampla defesa, já que declarar ou não declarar corresponde a um meio de defesa.

Segundo Luigi Ferrajoli ${ }^{84}$, o nemo tenetur se detegere é uma máxima do garantismo processual acusatório, que é informado pela presunção de inocência. Dessa máxima decorrem os corolários: a proibição de juramento; a proibição de métodos violentos ou que utilizem a manipulação da psique para obtenção de confissão; a negação do papel decisivo da confissão; o direito de ficar calado e a faculdade de mentir; o direito à assistência e presença de advogado defensor no interrogatório.

Entender a real razão de existência do direito à não autoincriminação é fundamental para resolver os problemas relativos à prova que dependa de colaboração do acusado. São exemplos os casos de intervenções corporais não consentidas, como extração de sangue e a coleta de material genético prevista pela Lei $12.654 / 2012^{85}$, tanto para apuração de crime quanto para compor um banco de dados para apuração futura.

André L. Nicolitt e Carlos R. Wehrs ${ }^{86}$ asseveram que não existe norma constitucional que autorize a restrição do direito à inviolabilidade e à integridade corporal nem da garantia contra a autoincriminação, que são direitos fundamentais. Estes são limites ao poder político. Acrescentam que a dignidade humana faz da pessoa um fim em si mesma e

84 FERRAJOLI, Luigi. Direito e razão: teoria do garantismo penal. Tradução de Ana Paula Zomer Sica et al., 3. ed., São Paulo: Revista dos Tribunais, 2010, p 559-560.

85 Disponível em: <http://www.planalto.gov.br/ccivil_03/_ato2011-2014/ 2012/lei/112654.htm>. Acesso em: 27 abr. 2018.

86 NICOLITT, André Luiz; WEHRS, Carlos Ribeiro. Intervenções corporais no processo penal e a nova identificação criminal: (lei 12.654/2012). 2. ed. rev., atual. e ampl. São Paulo: Revista dos Tribunais, 2015, p. 143 e 154. 
impede sua coisificação ou utilização como objeto. Assim, a violação da integridade física transgride a dignidade do acusado, sendo que a sua utilização como meio de obtenção de prova, o transforma em um objeto, em uma coisa.

Os autores ${ }^{87}$, refutando entendimento contrário, defendem que o direito fundamental de não autoincriminação veda a obrigatoriedade de colaboração do réu para a investigação ou instrução processual. Não há diferença se a colaboração forçada é ativa ou passiva, ou seja, um suportar passivamente alguma forma de intervenção, pois o acusado é utilizado como meio de prova, um objeto do processo, tanto em um quanto em outro caso.

\section{Conclusão}

O direito à não autoincriminação encontra-se previsto em vários documentos internacionais de direitos humanos, bem como na maioria das Constituições dos países democráticos. Portanto, é um direito humano e fundamental. No entanto, o fato deste direito se achar nesta posição de superioridade normativa não é o seu fundamento central. Pelo contrário, a importância advinda de seu real fundamento é que o faz ocupar essa posição de destaque.

São vários os fundamentos indicados para o direito à não autoincriminação. Demonstrou-se que o sistema acusatório, a presunção de inocência, a ampla defesa, o devido processo legal, a coibição da tortura ou de outros meios violentos para se obter uma declaração não se coadunam como fundamento central do direito à não autoincriminação. Evidenciam-se mais propriamente como decorrências ou um dos meios de possibilitar sua efetivação.

Verificou-se que a dignidade humana é a mais indicada como fundamento do direito à não autoincriminação. Aquela é o princípio motriz de todos os outros direitos individuais fundamentais. O direito de não autoincriminação tem, portanto, em última instância, fundamento naquele superprincípio.

87 Ibidem, p. 156-159. 
A dignidade humana é inerente ao ser humano, à sua essência, à sua natureza, e envolve vários elementos. Assim, faz-se necessária a delimitação suficiente do aspecto particular da dignidade humana que o direito à não autoincriminação visa proteger. Foram vários os aspectos particulares apresentados, como a integridade física e mental, a liberdade de autodeterminação e de consciência, a autopreservação, a liberdade moral e a intimidade.

Deduziu-se que o aspecto particular mais sólido da dignidade humana que enseja a existência do direito à não autoincriminação é a integridade mental e moral, que é violada ao ser o indivíduo colocado frente a possíveis disjuntivas desagradáveis, que formam o chamado "trilema", constituídas da possibilidade de dar origem a consequências negativas, seja por optar manter-se em silêncio ou declarar e, neste caso, por se autoincriminar ou por mentir. Isso transgride a natureza humana, que tem dificuldade de admitir as próprias falhas e assumir as consequências daí advindas.

Concluiu-se que o fundamento do direito à não autoincriminação é mais bem delimitado conjugando estes três fatores interligados: o "trilema", a natureza humana e a integridade mental e moral do indivíduo. Levando-se em conta a natureza humana, tem-se violada a integridade mental e moral do indivíduo quando colocado frente àquelas disjuntivas desagradáveis. Essa é a razão de existência do direito à não autoincriminação.

Concluiu-se, por fim, que o fundamento do direito à não autoincriminação reflete sua enorme relevância como garantia processual penal. Suas principais decorrências ou meios de possibilitar sua efetivação são: a proscrição do juramento; a proibição de tortura ou de qualquer meio violento ou ardiloso para obtenção de uma declaração; a não atribuição de qualquer consequência negativa ao silêncio ou à mentira do acusado, como o indício de culpabilidade, ainda que haja outras provas incriminatórias; o respeito à voluntariedade na participação da prova; a inadmissibilidade de provas obtidas com violação desse direito e de todas as derivadas dessa violação; o direito à informação prévia acerca da imputação que recai sobre si e de que tem direito ao silêncio e à defesa técnica; a observância do devido processo legal; o direito à ampla defesa, pela qual o acusado pode silenciar-se ou apresentar a versão dos fatos que lhe for mais favorável. 


\section{REFERÊNCIAS}

ALBUQUERQUE, Marcelo Schirmer. A garantia de não auto-incriminação: extensão e limites. Belo Horizonte: Del Rey, 2008.

ARAÚJO, Caroline. O princípio do nemo tenetur se detegere no crime de embriaguez ao volante: pièce de résistance no vale tudo probatório. Dissertação (de Mestrado em Ciências Criminais) - Programa de Pós-Graduação em Ciências Criminais, Pontifícia Universidade Católica o Rio Grande do Sul, Porto Alegre, 2015. Disponível em: <http://tede2.pucrs.br/tede2/handle/tede/6195>. Acesso em: 27 jan. 17.

ARAÚJO, Rochester Oliveira. O direito fundamental contra a autoincriminação: a análise a partir de uma teoria do Processo Penal Constitucional. Dissertação de (Mestrado em Constituição e Garantias de Direitos), Universidade Federal do Rio Grande do Norte, Natal, 2013. Disponível em: <https://repositorio.ufrn.br/ jspui/handle/123456789/13997>. Acesso em: 17 jan. 2017.

BERNATH, Javier Wilenmann Von. El tratamiento del autofavorecimiento del imputado. Sobre las consecuencias substantivas del principio de no autoincriminación. Revista de Derecho - Universidad Católica del Norte, Coquimbo (Chile), v. 23, n. 1, p. 111-139, jun. 2016. https://doi.org/10.4067/s0718-97532016000100006 BEUCHOT, Mauricio; JAVIER, Saldaña. Derechos humanos y naturaleza humana. Ciudad de México: Universidad Nacional Autónoma de México, 2000.

BIDART CAMPOS, Germán J. Teoría general de los derechos humanos. Edición al cuidado de Miguel López Ruiz. Ciudad de México: Universidad Nacional Autónoma de México, 1989.

BRAND, José Luis Eloy Morales. ¿Defensa o autoincriminación? Sobre la declaración del imputado en el sistema penal acusatorio. Redhes - Revista de Derechos Humanos y Estudios Sociales, San Luis Potosí (México), ano VI, n. 12, p. 123-144, jul.-dez. 2014.

BUSTOS, Miguel Ángel Caccha. El derecho a no autoincriminar-se en los procesos penales en el Distrito Judicial de Lima Sur, Tese para obter o título profissional de advogado - Facultad de Humanidades - Escuela Profesional de Derecho, Universidad Autónoma del Perú, Lima, 2016. Disponível em: <http://hdl.handle.net/ AUTONOMA/144>. Acesso em: 4 abr. 2017.

CATENA, Víctor Moreno. Sobre o princípio da presunção de inocência. Revista CEJ, Brasília, ano XIX, n. 67, p. 101-111, set.-dez. 2015. Disponível em: <http:// www.jf.jus.br/ojs2/index.php/revcej/issue/view/128>. Acesso em: 3 maio 2017. CHARNIAK, Krystina. LegaVox.fr: The right to remain silent in UK and in USA, 1 set. 2012. Disponível em: <https://www.legavox.fr/blog/charniak-krystina/ right-remain-silent-9376.htm>. Acesso em: 28 abr. 2017. 
ECHAGÜE, Juan Manuel Álvarez. Reflexiones sobre el alcance del estado de inocencia y del principio de no autoincriminación en el derecho penal tributario. Revista de Tributación de la Asociación Argentina de Estudios Fiscales, Buenos Aires, n. 6, 2007. Disponível em: <http://www.aeyasoc.com.ar/articulo26.pdf>. Acesso em: 25 jul. 2017.

ESCOBAR, Norma Valeria Torres. El principio de no autoincriminación en el derecho procesal penal. Tese para obtenção do título de advogada - Carrera de Derecho - Facultad de Jurisprudencia, Universidad Regional Autónoma de los Andes UNIANDES, Ibarra (Equador), 2014. Disponível em: <http://dspace.uniandes. edu.ec/handle/123456789/2609>. Acesso em: 4 abr. 2017.

FERNANDEZ, Atahualpa. O problema da natureza humana (parte 1 e 2). Empório do Direito, Florianópolis/SC, jul. 2015. Disponível em: <http://emporiododireito. com.br/leitura/o-problema-da-natureza-humana-parte-1 > e <http://emporiododireito.com.br/leitura/o-problema-da-natureza-humana-parte-2>. Acesso em 12 abr. 2018.

FERRAJOLI, Luigi. Direito e razão: teoria do garantismo penal. Tradução de Ana Paula Zomer Sica et al., 3. ed., São Paulo: Revista dos Tribunais, 2010.

GUEDES, Gabriel Pinto. O direito a não produzir prova contra si mesmo: aproximações entre os cases da Corte Interamericana de Direitos Humanos e do Supremo Tribunal Federal. Dissertação (Mestrado) - Programa de Pós-Graduação em Ciências Criminas, Pontifícia Universidade Católica do Rio Grande do Sul, Porto Alegre, 2014. Disponível em: <http://tede2.pucrs.br/tede2/handle/tede/4979>. Acesso em: 27 jan. 17.

HADDAD, Carlos Henrique Borlido: Conteúdo e contornos do princípio contra a auto-incriminação. Tese de (Doutorado em Direito) - Faculdade de Direito da Universidade Federal de Minas Gerais, Belo Horizonte, 2003. Disponível em: <http://hdl.handle.net/1843/BUOS-96KKJQ>. Acesso em: 9 nov. 2016.

HAPNER, Andrew M. You have the right to remain silent, but anything you don't say may be used against you: the admissibility of silence as evidence after Salinas v. Texas. Florida Law Review, Gainesville (Florida/U.S.), v. 66, n. 4, Article 8, p. 1763-1778, fev. 2015. Disponível em: <https://scholarship.law.ufl.edu/cgi/viewcontent.cgi?article=1216\&context=flr >. Acesso em: 17 abr. 2018.

KITAI-SANGERO, Rinat. Respecting the privilege against self-incrimination: a call for providing Miranda warnings in non-custodial interrogations. New Mexico Law Review, Albuquerque (U.S.), v. 42, p. 203-235, 9 Dez. 2012. Disponível em: <https://ssrn.com/abstract=2187044>. Acesso em: 4. Abr. 2017. 
NICOLITT, André Luiz; WEHRS, Carlos Ribeiro. Intervenções corporais no processo penal e a nova identificação criminal: (lei 12.654/2012). 2. ed. rev., atual. e ampl. São Paulo: Revista dos Tribunais, 2015.

PERALTA, José Milton. La no obligación de declarar contra uno mismo. In: RIVERA, Julio C. (h) et al. Tratado de los derechos constitucionales. Buenos Aires: Abeledo Perrot, v. 3. Cap. 4, p. 399-439, 2014.

QUEIJO, Maria Elizabeth. O direito de não produzir prova contra si mesmo: o princípio nemo tenetur se detegere e suas decorrências no processo penal. 2. ed. São Paulo: Saraiva, 2012.

QUINATOA, Angélica Marlene Yugcha. El garantismo constitucional frente al principio de legalidad y el derecho a la no incriminación en el procedimiento abreviado en la legislación penal ecuatoriana. Tese para obtenção do título de advogada - Escuela de Derecho - Facultad de Jurisprudencia, Ciencias Políticas y Sociales, Universidad Central del Ecuador, Quito, jun. 2014. Disponível em: <http://www.dspace.uce. edu.ec/handle/25000/3219>. Acesso em: 4 abr. 2017.

RIVEROS-BARRAGÁN, Juan David. El derecho a guardar silencio: visión comparada y caso colombiano. Revista Colombiana Derecho Internacional, Bogotá (Colômbia), n. 12, Ed. Especial, p. 373-394, 2008. ISSN 1692-8156. Disponível em: <http:// www.scielo.org.co/pdf/ilrdi/n12/n12a14.pdf>. Acesso em: 13 abr. 2017.

TROIS NETO, Paulo Mário Canabarro. O direito fundamental à não-autoincriminação e a influência do silêncio do acusado no convencimento do juiz penal. Dissertação (Mestrado) - Programa de Pós-Graduação em Direito, Universidade Federal do Rio Grande do Sul, Porto Alegre, 2009. Disponível em: <https://www.lume.ufrgs. br/bitstream/handle/10183/142763/000717713.pdf? sequence=1 $>$. Acesso em: 17 jan. 2017.

WALCHER, Guilherme Gehlen. A garantia contra a autoincriminação no Direito brasileiro: breve análise da conformação do princípio nemo tenetur se detegere à luz da jurisprudência nacional e estrangeira. Revista de Doutrina da $4^{a}$ Região, Porto Alegre, n. 57, 18 dez. 2013. Disponível em: <http://www.revistadoutrina. trf4.jus.br/index.htm?http://www.revistadoutrina.trf4.jus.br/artigos/edicao057/ Guilherme_Walcher.html>. Acesso em: 4 abr. 2017.

YOKOYAMA, Marcia Caceres Dias. O direito ao silêncio no interrogatório. Dissertação de (Mestrado em Direito) - Pontifícia Universidade Católica de São Paulo, São Paulo, 2007. Disponível em: <https://tede2.pucsp.br/handle/handle/7829>. Acesso em: 9 nov. 2016. 


\section{Informações adicionais e declarações dos autores (integridade cientifica)}

Agradecimentos (acknowledgement): Gratidão ao Prof. Dr. Ezequiel Abásolo por sua dedicada e enriquecedora orientação.

Declaração de conflito de interesses (conflict of interest declaration): a autora confirma que não há conflitos de interesse na realização das pesquisas expostas e na redação deste artigo.

Declaração de autoria e especificação das contribuições (declaration of authorship): todas e somente as pessoas que atendem os requisitos de autoria deste artigo estão listadas como autores.

Declaração de ineditismo e originalidade (declaration of originality): a autora assegura que o texto aqui publicado não foi divulgado anteriormente em outro meio e que futura republicação somente se realizará com a indicação expressa da referência desta publicação original; também atesta que não há plágio de terceiros ou autoplágio. 
Dados do processo editorial

(http://www.ibraspp.com.br/revista/index.php/RBDPP/about/editorialPolicies)

- Recebido em: 27/12/2017

- Deslocamento ao V4N2 comunicado aos autores: 14/01/2018

- Controle preliminar e verificação de plágio: 24/02/2018

- Avaliação 1: 11/03/2018

Equipe editorial envolvida

- Editor-chefe: 1 (VGV)

- Editor-assistente: 1 (RDG)

- Revisores: 3

- Avaliação 2: 15/03/2018

- Avaliação 3: 21/03/2018

- Decisão editorial preliminar: 07/04/2018

- Retorno rodada de correções 1: 28/04/2018

- Decisão editorial preliminar 2: 02/05/2018

- Retorno rodada de correções 2: 04/05/2018

- Decisão editorial final: 05/05/2018

\section{COMO CITAR ESTE ARTIGO:}

CARVALHO, Heloisa Rodrigues Lino de. Fundamento central do direito à não autoincriminação. Revista Brasileira de Direito Processual Penal, Porto Alegre, vol. 4, n. 2, p. 731-765, mai./ago. 2018. https://doi.org/10.22197/rbdpp.v4i2.134

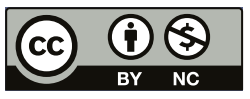

Esta obra está licenciada com uma Licença Creative Commons Atribuição-NãoComercial 4.0 Internacional. 